\title{
Pengaruh Kredit UMKM Terhadap Tingkat Pengangguran Terbuka Kabupaten/Kota di Provinsi Jawa Barat Tahun 2015-2019
}

\author{
(Effect of Micro-credit to Unemployment Rate Regencies/Cities \\ in West Java Province on 2015-2019) \\ Yogi Juniarto $^{1 *}$, Siti Muchlisoh ${ }^{2}$ \\ 1,2 Politeknik Statistika STIS \\ Jalan Singgalang 7 Tangkerang Timur, Tenayan Raya, Pekanbaru, Riau. 28289 \\ E-mail:211710067@stis.ac.id
}

\begin{abstract}
ABSTRAK
Pengangguran merupakan salah satu permasalahan yang selalu dihadapi oleh suatu negara tidak terkecuali di Indonesia. UMKM muncul sebagai salah satu lapangan pekerjaan yang sangat berkembang di Indonesia. Dengan terus berkembangnya jumlah UMKM di Indonesia memunculkan adanya kebijakan pemberian kredit UMKM dengan harapan UMKM dapat semakin berkembang dan mampu membuka lebih banyak lapangan kerja baru, sehingga tingkat pengangguran dapat ditekan. Provinsi Jawa Barat menjadi salah satu dari tiga provinsi yang memiliki jumlah kredit UMKM tertinggi di Indonesia. Penelitian ini bertujuan untuk mengidentifikasi apakah pemberian kredit UMKM dapat berpengaruh signifikan dalam menurunkan tingkat pengangguran di Jawa Barat. Berdasarkan hasil penelitian menggunakan metode regresi data panel dengan model FEM SUR, ditemukan bahwa pemberian kredit UMKM secara signifikan berhasil menurunkan tingkat pengangguran di Jawa Barat.
\end{abstract}

Kata kunci: Pengagguran, Kredit UMKM, Regresi Data Panel

\begin{abstract}
Unemployment is one of the problems that are always faced by a country, including Indonesia. Micro-business have emerged as one of the most developed jobs in Indonesia. With the continued growth of the number of micro-business in Indonesia, there is a policy of providing micro-credit with the hope that micro-business can grow and be able to open more new jobs, so that the unemployment rate can be suppressed. West Java Province is one of the three provinces that have the highest number of micro-credit in Indonesia. This study aims to identify whether the provision of micro-credit can have a significant effect in reducing the unemployment rate in West Java. Based on the results of the study using the panel data regression method with the FEM SUR model, it was found that the provision of micro-credit significantly succeeded in reducing the unemployment rate in West Java.
\end{abstract}

Keywords: Unemployment, Micro-credit, Panel Regression

\section{PENDAHULUAN}

Salah satu masalah yang dihadapi oleh sebagian besar negara adalah pengangguran. Pengangguran tidak hanya berarti masalah sosial, tetapi juga masalah ekonomi. Hal ini dikarenakan pengangguran tidak hanya menimbulkan masalah sosial, tetapi juga mempengaruhi pertumbuhan ekonomi negara, terutama di negara berkembang seperti Indonesia. Sukirno (2004) menyatakan bahwa pengangguran adalah salah satu masalah ekonomi makro selain pertumbuhan ekonomi, ketidakstabilan kegiatan ekonomi, kenaikan harga-harga (inflasi), dan neraca perdagangan dan pembayaran. Tingkat pengangguran yang tinggi akan menyebabkan masalah multidimensional seperti meningkatnya kriminalitas dan menurunnya kesejahteraan masyarakat. Perkembangan ekonomi dan tingkat kesejahteraan suatu negara dapat diukur berdasarkan tingkat pengangguran (Sukirno, 2004). Oleh sebab itu, pengangguran selalu menjadi fokus kinerja pemerintah yang menjadi perhatian dari tahun ke tahun. 


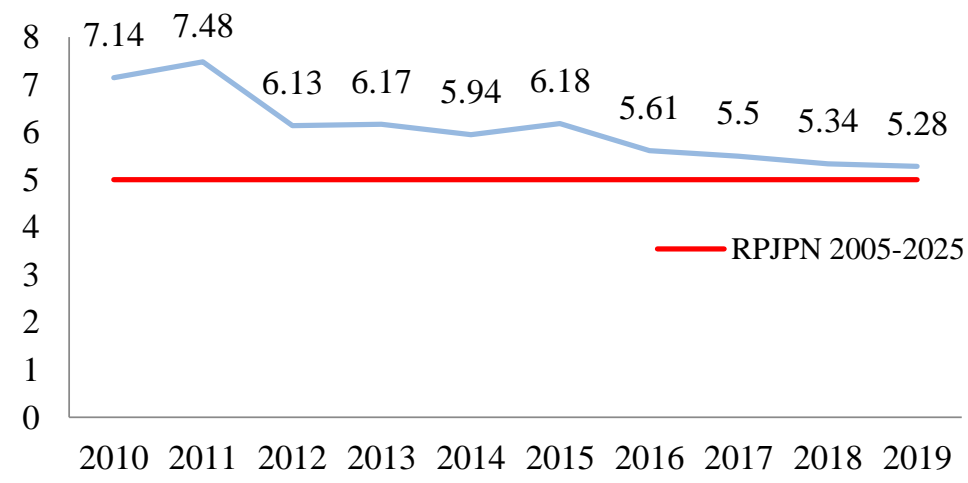

Sumber: Badan Pusat Statistik (diolah)

Gambar 1. Perkembangan Tingkat Pengagguran Terbuka Indonesia, Tahun 2010-2019.

Berdasarkan Gambar 1, dapat dilihat Tingkat Pengangguran Terbuka (TPT) di Indonesia sepanjang tahun 2010 hingga 2019 cenderung menurun. Meski demikian, masih belum mencapai misi yang ditetapkan dalam Rencana Pembangunan Jangka Panjang Nasional (RPJPN) tahun 2005-2025 dimana menjadikan tingkat pengangguran di Indonesia berada dibawah angka 5 persen (Badan Perencanaan dan Pembangunan Nasional, 2017). Sehingga pemerintah masih berupaya untuk menurunkan tingkat pengangguran, salah satu caranya adalah dengan pengembangan Usaha Miko, Kecil dan Menengah (UMKM).

Tabel 1. Perkembangan UMKM Indonesia tahun 2015-2019

\begin{tabular}{llccc}
\hline \multirow{2}{*}{ Tahun } & \multicolumn{3}{c}{ UMKM } & \multicolumn{2}{c}{ Tenaga Kerja } \\
\cline { 2 - 5 } & Jumlah & Pangsa $(\%)$ & Jumlah & Pangsa (\%) \\
\hline 2015 & 59.262 .772 & 99,99 & 123.229 .387 & 96,71 \\
2016 & 61.651 .177 & 99,99 & 112.828 .610 & 97,04 \\
2017 & 62.922 .617 & 99,99 & 116.431 .224 & 96,82 \\
2018 & 64.194 .057 & 99,99 & 116.978 .631 & 97,00 \\
2019 & 65.465 .497 & 99,99 & 119.562 .843 & 96,92 \\
\hline
\end{tabular}

Sumber: Kementrian Koperasi dan UMKM

Berdasarkan Tabel 1 sepanjang tahun 2015 hingga 2019, secara umum jumlah UMKM di Indonesia menguasai 99,99 persen pangsa pasar dan sebesar 97 persen tenaga kerja diserap oleh UMKM yang ada. Dari informasi tersebut, UMKM memiliki potensi untuk menjadi salah satu sektor yang dapat berkembang serta dapat menjadi salah satu opsi lapangan kerja di Indonesia. Untuk mengembangkan dan memperluas UMKM dibutuhkan modal, sehingga pemerintah melalui bank menyalurkan kredit UMKM. Sepanjang tahun 2015 hingga 2019, kredit UMKM di Indonesia terus mengalami peningkatan dari tahun ke tahun. UMKM yang berada di pulau Jawa menerima kredit UMKM lebih dari 50 persen dari seluruh kredit UMKM yang dikeluarkan untuk seluruh daerah di Indonesia.

Manihuruk dan Meirinaldi (2018) dalam penelitiannya menyatakan bahwa pemberian kredit UMKM oleh bank BUMN dapat mengurangi tingkat pengangguran di Indonesia. Sipahutar, Oktaviani, Siregar, dan Juanda (2016) dalam penelitiannya menyatakan bahwa pemberian kredit dapat meningkatkan bisnis di sektor riil karena perluasan ketersediaan modal dan likuiditas, sehingga dapat meningkatkan permintaan tenaga kerja dan cenderung menurunkan tingkat pengangguran. Ncanywa dan Getye (2016) dalam penelitiannya juga menyatakan bahwa pembiayaan kredit kecil terkadang direkomendasikan sebagai alat untuk mengurangi pengangguran dan dapat berdampak positif pada penciptaan lapangan kerja di Afrika Selatan. Mahroji dan Nurkhasanah (2019), menyatakan bahwa Indeks Pembangunan Manusia (IPM) berpengaruh signifikan negatif terhadap pengangguran di Banten. Dengan naiknya IPM, tingkat pengangguran di Banten turun. Dalam penelitiannya, Priastiwi dan Handayani (2019) menuliskan jumlah penduduk memiliki dampak signifikan positif terhadap pengangguran di Jawa Tengah.

Sepanjang tahun 2015 hingga 2019 DKI Jakarta, Jawa Timur, dan Jawa Barat secara berurutan menjadi 3 provinsi yang menerima kredit UMKM terbesar di pulau Jawa maupun secara nasional. Meskipun menerima jumlah kredit UMKM yang besar, nyatanya provinsi Jawa Barat masih belum mampu mengatasi permasalahan pengangguran di daerahnya. Hal tersebut dapat terlihat dari TPT yang masih berada diatas TPT nasional. Selain itu, TPT Jawa Barat juga berada pada urutan kedua tertinggi di Jawa setelah Banten. Sedangkan Provinsi DKI Jakarta dan Jawa Timur yang memiliki jumlah kredit UMKM lebih besar dibandingkan Jawa Barat, memiliki angka TPT lebih rendah dibandingkan Provinsi Jawa Barat. 


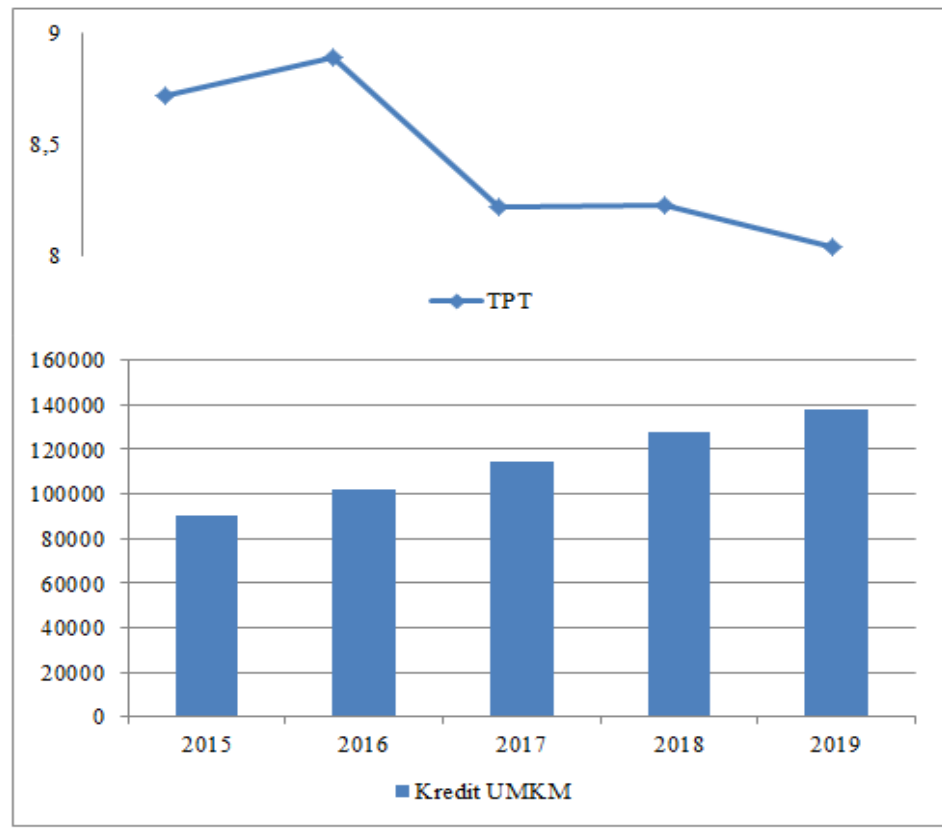

Sumber: Badan Pusat Statistik dan Otoritas Jasa Keuangan (diolah)

Gambar 2. Perkembangan Tingkat Pengagguran Terbuka dan Jumlah Kredit UMKM Jawa Barat, Tahun 2015-2019.

Pada Gambar 2, dapat dilihat bahwa kredit UMKM konsisten meningkat tiap tahunnya sepanjang tahun 2015 hingga 2019. Namun, TPT Jawa Barat masih berfluktuasi dalam periode yang sama. Hal tersebut mengindikasikan bahwa provinsi Jawa Barat masih belum mampu memaksimalkan jumlah kredit UMKM yang diterima dalam hal mengatasi pengangguran di daerahnya. Sehingga penelitian ini bertujuan untuk mengidentifikasi pengaruh kredit UMKM terhadap TPT di Provinsi Jawa Barat tahun 2015-2019. Penelitian memiliki kontribusi dengan menggunakan wilayah observasi yang lebih khusus yaitu dengan menganalisa wilayah provinsi dimana pada penelitian-penelitian sebelumnya masih menggunakan wilayah observasi secara nasional. Selain itu pada penelitian ini juga menggunakan tahun yang terbaru yaitu tahun 2015 hingga 2019.

Berdasarkan identifikasi masalah dan penelitian terkait sebelumnya dapat disusun hipotesis penelitian sebagai berikut :

1. Kredit UMKM memiliki pengaruh terhadap TPT di Provinsi Jawa Barat.

2. Jumlah penduduk memiliki pengaruh terhadap TPT di Provinsi Jawa Barat.

3. Indeks Pembangunan Manusia memiliki pengaruh terhadap TPT di Provinsi Jawa Barat.

\section{METODE}

Menurut Mankiw (2007), tabungan dan investasi merupakan interpretasi dari kaidah hubungan penawaran-permintaan pinjaman atau dana kredit. Dalam hal ini, aset adalah dana pinjaman dan harganya adalah tingkat bunga. Tabungan adalah penyediaan dana pinjaman.Semakin tinggi tingkat bunga, semakin besar keinginan untuk menabung. Dan investasi adalah permintaan dana pinjaman. Karena suku bunga rendah, investor cenderung meminjam langsung dari masyarakat melalui penjualan obligasi atau secara tidak langsung meminjam dari masyarakat melalui pinjaman dari bank. Dana pinjaman yang besar mengindikasikan adanya investasi yang besar pula. Investasi akan berdampakpada pertambahn modal dan mendorong bertambahnya output. Bertambahnya output dapat terjadi bersamaan dengan bertambahnya modal. Pertambahan modal dapat berupa pertambahan barang-barang modal untuk proses produksi maupun pertambahan tenaga kerja yang dibutuhkan. Bertambahnya penawaran tenaga kerja dari perusahaan berpotensi untuk mengurangi pengangguran.

Menurut Todaro dan Smith (2011), pembangunan manusia merupakan salah satu tujuan pembangunan. Pembangunan manusia di sana akan mampu menciptakan tenaga kerja yang dapat menyerap teknologi modern untuk mengembangkan kemampuannya dalam menciptakan lapangan kerja dan mengurangi pengangguran. 
Berdasarkan Teori Kependudukan Malthus, pertumbuhan penduduk yang semakin cepat akan sejalan dengan pertumbuhan tenaga kerja, namun tidak seimbang dengan perluasan kesempatan kerja. Ketidakseimbangan ini menyebabkan manusia saling bersaing untuk masuk ke dalam dunia kerja. Seseorang yang tidak mendapatkan kesempatan kerja akan menjadi pengangguran (Lindiarta, 2014).

Metode analisis yang digunakan adalah regresi data panel, dimana pemilihan metode regresi data panel didasarkan dengan alasan data yang berjenis data panel. Dimana data panel itu sendiri merupakan gabungan dari data time series dan cross section yang berada pada unit cross section yang sama (Gujarati, 2004). Model umum pada penelitian ini adalah sebagai berikut :

$T P T_{i t}=\alpha_{i}+\beta_{1} L N_{-} K R E D I T_{i t}+\beta_{2} L N_{\lrcorner} J P_{i t}+\beta_{3} I P M_{i t}+u_{i t}$

dimana:

TPT = Tingkat Pengangguran Terbuka (persen)

$L N \_K R E D I T=$ kredit UMKM (rupiah)

$L N_{-} J P \quad=$ jumlah penduduk (jiwa)

$I P M \quad=$ indeks pembangunan manusia

$\alpha \quad=$ konstanta

$\beta \quad=$ koefisien regresi

$i \quad=$ kabupaten $/$ kota

$t \quad=$ tahun

$u=$ error term

Sebelum menemukan model serta metode estimasi regresi data panel yang tepat, maka dilakukan beberapa tahap sebagai berikut :

1. Pemilihan model yang terbaik, dengan model umum regresi data panel seperti pada persamaan (1). Pada regresi data panel, terdapat 3 jenis model yang dapat digunakan untuk melihat hubungan antara variabel independen dengan variabel dependen. Common Effect Model (CEM), Fixed Effect Model (FEM), dan Random Effect Model (REM) adalah ketiga model pada analisis regresi data panel tersebut. Uji yang digunakan dalam pemilihan ini adalah uji Chow (CEM vs FEM), uji Hausman (FEM vs REM), dan uji Lagrange Multiplier (REM vs CEM).

2. Pengujian varians-kovarians residual. Pengujian varians-kovarians residual digunakan untuk melihat metode estimasi yang digunakan dalam model.

3. Setelah menguji struktur varians-kovarians residual dari model yang terpilih, maka tahapan selanjutnya adalah pengujian asumsi klasik. Pengujian asumsi klasik menurut. Gujarati, (2004) terdapat 4, yaitu uji normalitas, uji multikolinieritas, uji heterogenitas, dan uji autokorelasi.

4. Apabila asumsi klasik terpenuhi, tahapan selanjutnya adalah pengujian keberartian. Uji keberartian terdiri dari 3 pengujian, yaitu Goodness Of Fit (R2), uji simultan (F), dan uji parsial (T). Setelah pengujian tersebut selesai, langkah selanjutnya adalah interpretasi.

\section{Data dan Sumber Data}

Penelitian ini menggunakan data panel dari 26 kabupaten/kota di Provinsi Jawa Barat dengan periode tahun 2015 hinga 2019. Variabel dependen yang digunakan digunakan dalam penelitian ini adalah Tingkat Pengangguran Terbuka (TPT), sedangkan variabel independen yang digunakan adalah jumlah kredit UMKM, Indeks Pembangunan Manusia (IPM), dan jumlah penduduk. Data yang digunakan dalam penelitian ini adalah data sekunder yang diperoleh dari Badan Pusat Statistik (untuk variabel TPT, IPM, dan jumlah penduduk) dan Otoritas Jasa Keuangan (untuk variabel kredit UMKM).

\section{Definisi Operasional}

1. TPT adalah persentase pengangguran dalam total angkatan kerja.

2. Kredit UMKM adalah uang atau utang yang diberikan berdasarkan perjanjian pinjam meminjam antara bank dengan UMKM.

3. Indeks Pembangunan Manusia adalah ukuran keberhasilan pembangunan manusia berdasarkan komponen kualitas hidup.

4. Penduduk adalah jumlah orang yang tinggal di suatu wilayah selama periode waktu tertentu. 


\section{HASIL DAN PEMBAHASAN}

\section{Gambaran umum Tingkat Pengangguran Terbuka Provinsi Jawa Barat}

Provinsi Jawa Barat menjadi salah satu provinsi dengan TPT tertinggi di Indonesia setelah provinsi Banten di tahun 2019. Sepanjang tahun 2015 hingga 2019, TPT provinsi Jawa Barat selalu berada diatas angka 8 persen dimana angka tersebut sangat jauh dari angka TPT nasional dan target TPT didalam RPJPN 2005-2025 yaitu dibawah angka 5 persen. Gambaran tingkat pengangguran Provinsi Jawa Barat pada tahun 2015 hingga 2019 dapat dilihat pada Gambar 2.

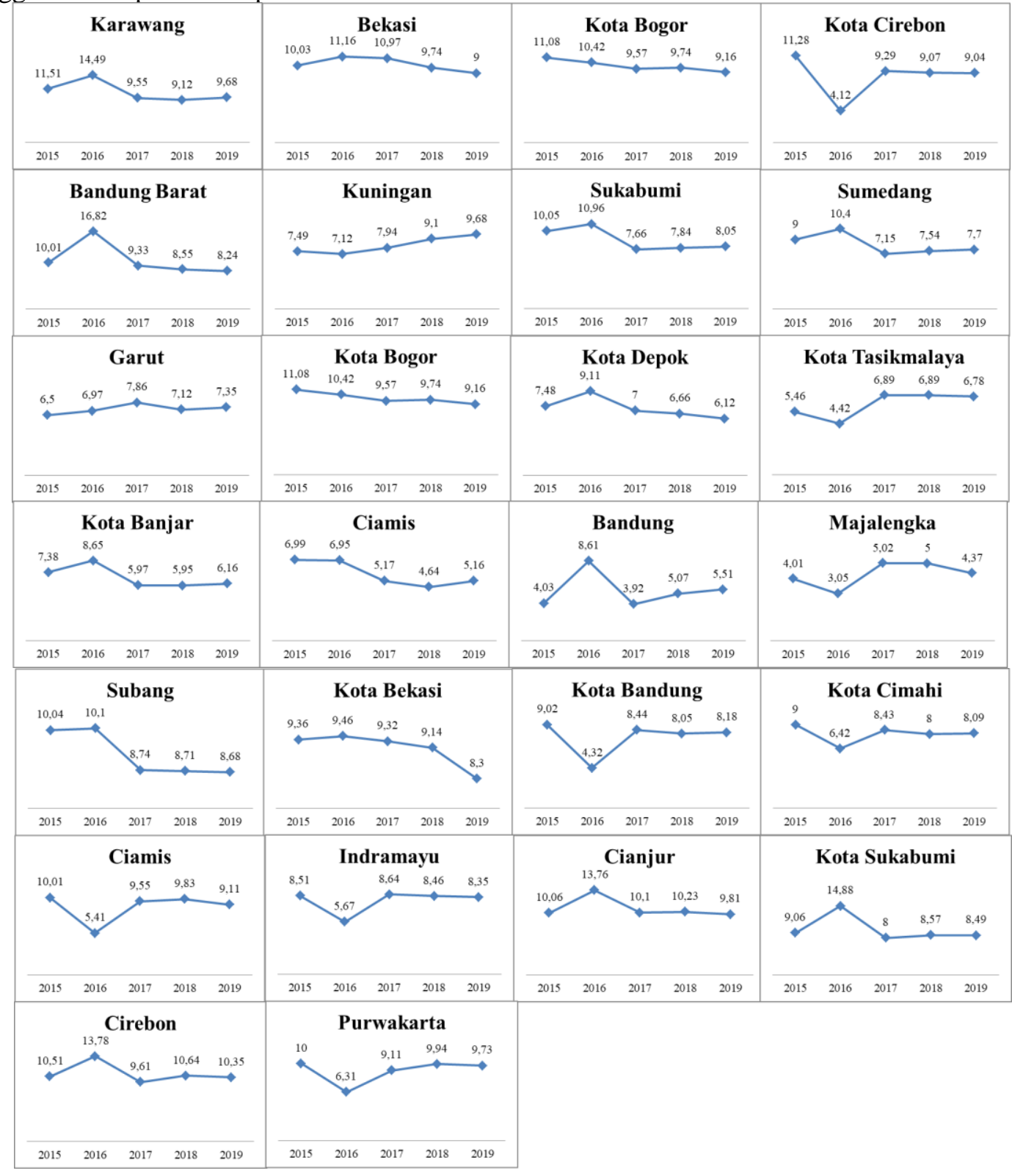

Sumber: Badan Pusat Statistik dan Muhammad Fadli (diolah)

Gambar 3. Perkembangan Tingkat Pengangguran Terbuka Berdasarkan Kabupaten/Kota di Jawa Barat, 2015-2019.

Berdasarkan Gambar 2, dapat diperoleh informasi bahwa TPT Jawa Barat sepanjang tahun 2015 hingga 2019 mengalami fluktuasi dan cenderung menurun. Angka pengangguran tertinggi terjadi pada tahun 2016 yang mencapai 8,89 persen sedangkan terendah terjadi pada tahun 2019 yang mencapai 8,04 persen. Sepanjang tahun 2015 hingga 2019, angka pengangguran Provinsi Jawa Barat mengalami penurunan. Namun, angka tersebut masih jauh dari angka yang telah ditargetkan dalam RPJMN 2015-2019 dimana target TPT adalah 4 hingga 5 persen serta target kedepannya yaitu RPJMN 2020-2024 dengan target TPT adalah 4 hingga 4,6 persen. 
Berdasarkan Gambar 3, dapat dilihat perkembangan TPT di setiap kabupaten/kota di Jawa Barat. Sepanjang tahun 2015 hingga 2019, pergerakan TPT sebagian besar kabupaten/kota di Jawa Barat cenderung stabil dimana tidak terdapat pergerakan yang sangat fluktuatif di setiap tahunnya. Hanya ada dua kabupaten yang memiliki pergerakan TPT yang sangat fluktuatif yakni kabupaten Cirebon dan Purwakarta. Sebagian besar kabupaten/kota di Jawa Barat memiliki rentang TPT diangka 6 sampai 11 persen dimana hanya tiga kabupaten yang memiliki TPT dibawah 6 persen yakni kabupaten Ciamis, Bandung, dan Majalengka. Hal ini yang menyebabkan TPT provinsi Jawa Barat berada di urutan tiga besar TPT tertinggi di Indonesia.

\section{Gambaran umum kredit UMKM Provinsi Jawa Barat}

Berdasarkan Gambar 2, Kredit UMKM provinsi Jawa Barat sepanjang tahun 2015 hingga 2019 meningkat tiap tahunnya dari angka 90 triliun rupiah hingga 137 triliun rupiah. Dimana peningkatan tiap tahunnya konsisten sekitar \pm 10 triliun rupiah. Hal tersebut menunjukkan stabilnya perkembangan UMKM di provinsi Jawa Barat dari tahun ke tahun. Gambar 4 menunjukkan persebaran kredit UMKM pada kabupaten/kota Provinsi Jawa Barat. Kota Bandung menjadi kota yang memiliki jumlah kredit UMKM tertinggi baik padatahun 2015 maupun 2019. Hal tersebut dapat terjadi karena Kota Bandung merupakan ibukota provinsi Jawa Barat sekaligus pusat perekonomian provinsi Jawa Barat. Selain itu, Kota Bandung juga merupakan salah satu destinasi wisata bagi masyarakat Jawa Barat maupun luar Jawa Barat. Sehingga UMKM di Kota Bandung memiliki jumlah yang tinggi dan otomatis membutuhkan kredit UMKM yang tinggi pula.

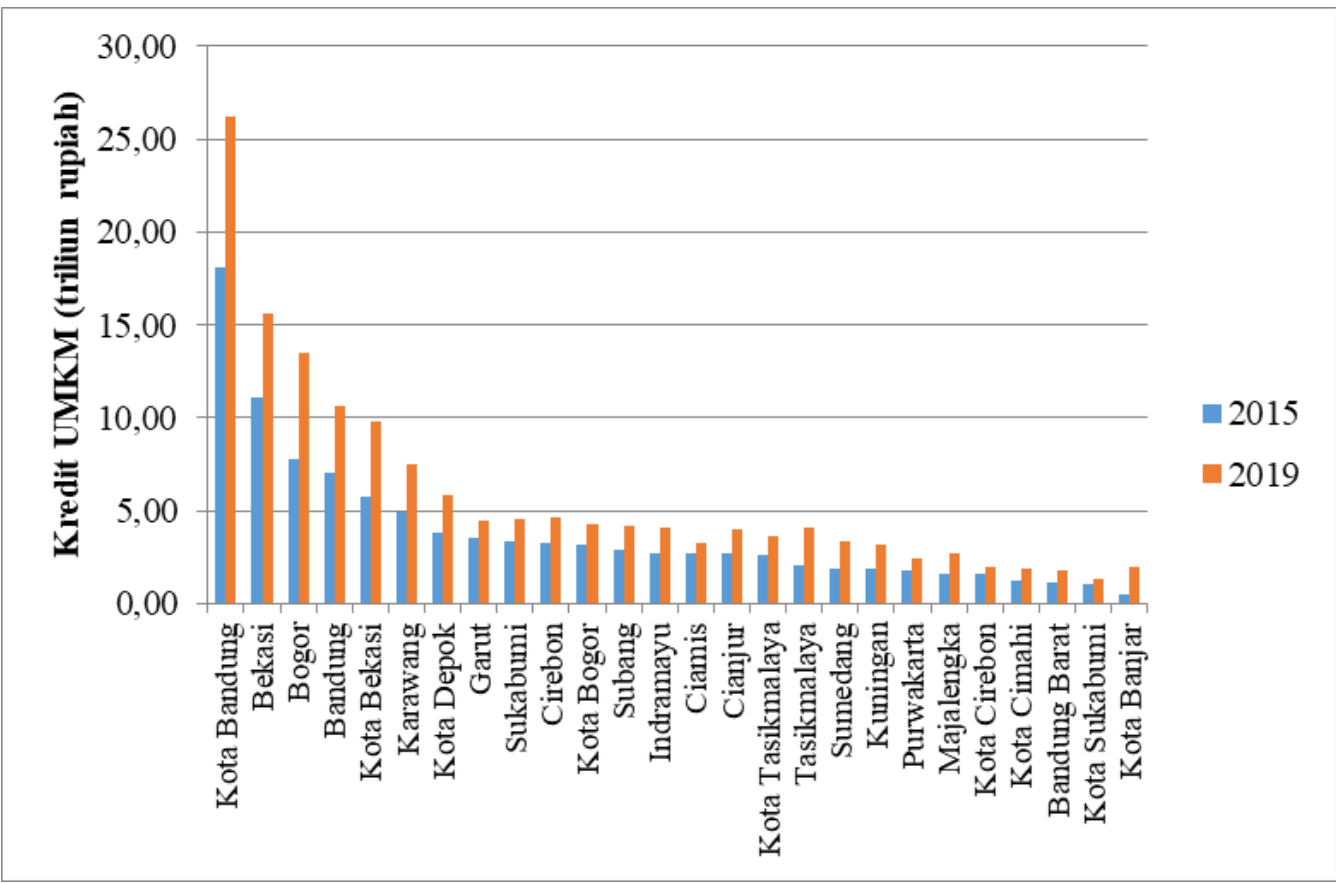

Sumber: Otoritas Jasa Keuangan (diolah)

Gambar 4. Kredit UMKM Kabupaten/Kota di Jawa Barat, Tahun 2015 dan 2019.

\section{Gambaran umum jumlah penduduk Provinsi Jawa Barat}

Berdasarkan Gambar 5, dapat dilihat masih belum meratanya penyebaran jumlah penduduk antar kabupaten/kota di Provinsi Jawa Barat. Hal ini dapat disebabkan oleh beberapa faktor, antara lain luas wilayah kabupaten tersebut atau bahkan taraf hidup disana yang bagus sehingga menarik perhatian orang untuk menetap disana. Pada tahun 2015 dan 2019, Kabupaten Bogor menjadi daerah yang memiliki jumlah penduduk tertingi di Jawa Barat dengan jumlah penduduk sebanyak 5,45 dan 5,96 juta jiwa. Sedangkan Kota Banjar menjadi daerah yang memiliki jumlah penduduk terendah dengan jumlah penduduk sebanyak 181 dan 183 ribu jiwa. 


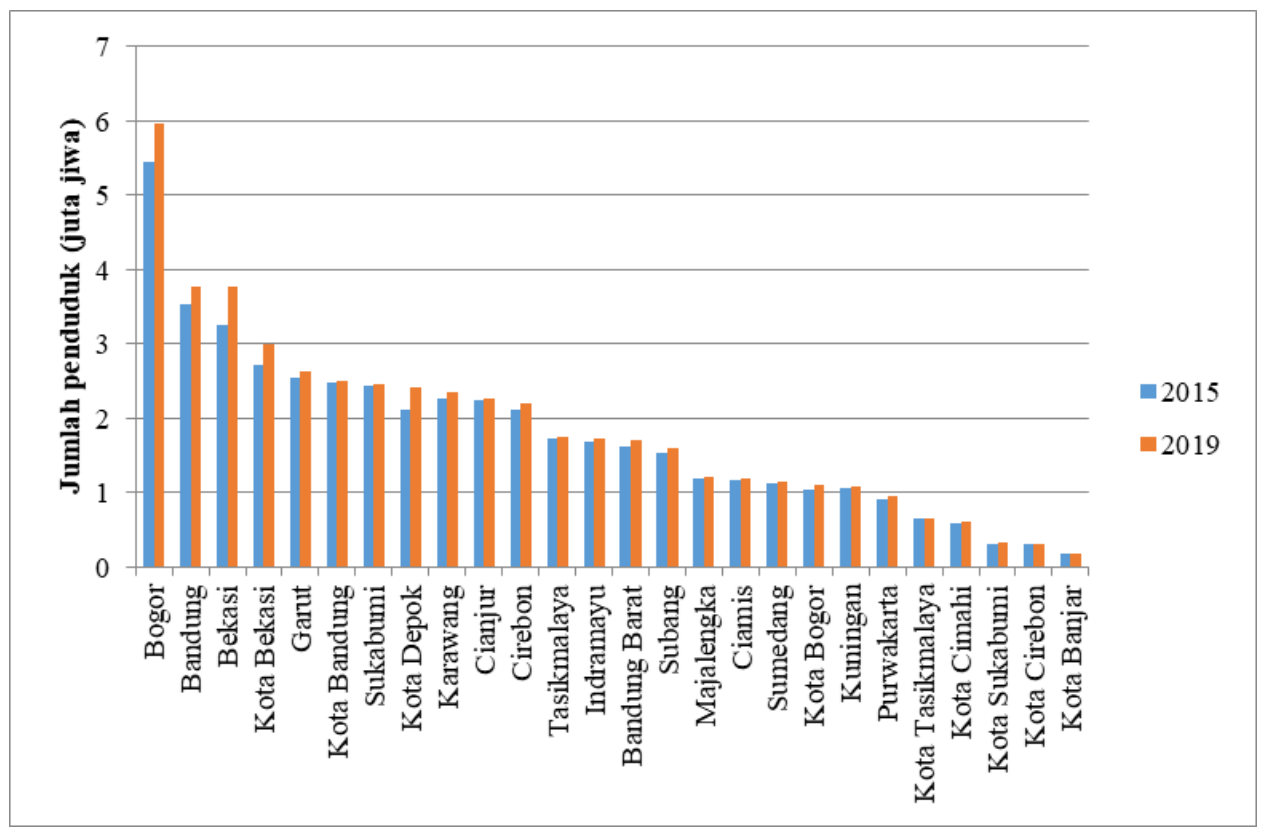

Sumber: Badan Pusat Statistik (diolah)

Gambar 5. Jumlah penduduk Kabupaten/Kota di Jawa Barat, Tahun 2015 dan 2019.

\section{Gambaran umum Indeks Pembangunan Manusia Provinsi Jawa Barat}

Berdasarkan Gambar 6, terlihat bahwa IPM disetiap kabupaten/kota di Jawa Barat memiliki nilai yang merata yakni berkisar diangka 60 hingga 80. Hal tersebut mengindikasikan bahwa tiap daerah di Jawa Barat memiliki kualitas sumber daya manusia yang hampir sama, yang merupakan hasil dari baiknya kualitas pendidikan serta kualitas kesehatan di Provinsi Jawa Barat. Pada tahun 2015 dan 2019, Kota Bandung merupakan daerah yang memiliki IPM tertinggi di Jawa Barat dengan IPM sebesar 79,67 dan 81,62. Sedangkan Kabupaten Cianjur memiliki IPM terendah dengan IPM sebesar 62,42 dan 65,38.

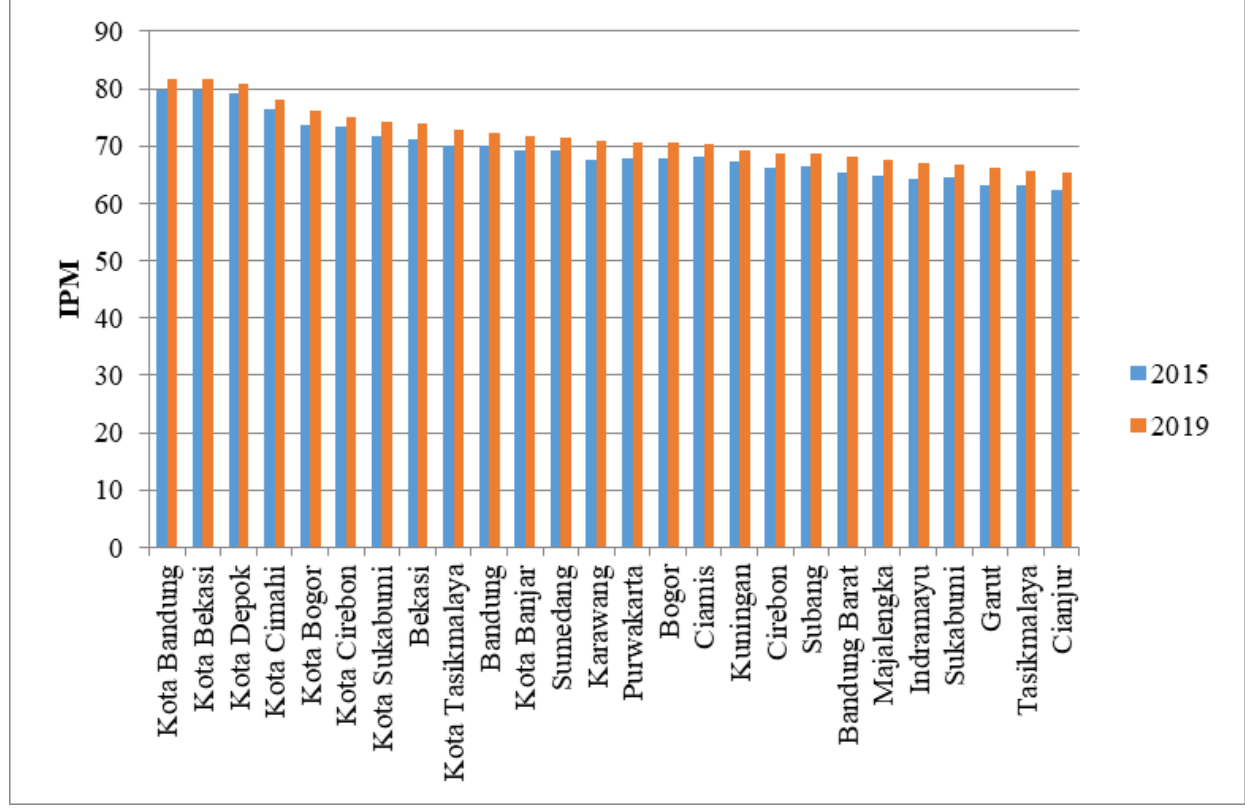

Sumber: Badan Pusat Statistik(diolah)

Gambar 6. Indeks Pembangunan Manusia Kabupaten/Kota di Jawa Barat, Tahun 2015 dan 2019.

\section{Pemilihan Model Terbaik}

Dalam memilih model terbaik, digunakan beberapa tahapan pengujian, yang pertama menggunakan uji Chow untuk menentukan model terbaik antara CEM dan FEM. Berdasarkan hasil uji Chow, dapat disimpulkan bahwa FEM lebih baik daripada CEM. Selanjutnya, digunakan uji Hausman untuk menentukan model terbaik antara FEM dan REM. Berdasarkan hasil uji Hausman dapat disimpulkan bahwa FEM lebih 
baik daripada REM. Oleh karena itu, berdasarkan dua pengujian tersebut dapat disimpulkan bahwa FEM merupakan model yang paling baik diantara model-model lainnya dalam regresi data panel pada penelitian ini.

Apabila model yang dipilih merupakan FEM, maka perlu dilakukan pengujian struktur varians kovarians residual untuk menentukan metode estimasi mana yang akan digunakan pada model tersebut. Langkah pertama dalam menguji struktur varians kovarians adalah dengan menggunakan uji Lagrange Multiplier (LM) untuk menguji ada tidaknya perbedaan varians (heteroskedastisitas) antar unit cross section. Berdasarkan hasil uji LM dapat disimpulkan bahwa struktur varians kovarians residual memiliki heteroskedastisitas, sehingga perlu dilakukan pengujian apakah terdapat cross-sectional correlation pada struktur varians kovarians residual. Pengujian yang dilakukan dalam pengujian ini adalah uji $\lambda \mathrm{LM}$, dan hasilnya adalah terdapat cross-sectional correlation pada struktur varians kovarians. Berdasarkan beberapa pengujian yang telah dilakukan, model yang digunakan dalam penelitian ini adalah FEM, menggunakan metode estimasi Feasible Generalized Least Square (EGLS/FGLS) dengan cross section Seemingly Unrelated Regression (SUR).

\section{Uji Asumsi Klasik}

Uji asumsi klasik digunakan untuk mengetahui apakah model yang digunakan bersifat Best Linear Unbiased Estimator (BLUE). Uji asumsi klasik yang harus dilakukan pada model ini adalah uji normalitas dan uji nonmultikolinearitas. Sedangkan untuk uji heteroskedastisitas dan uji nonautokorelasi tidak perlu untuk dilakukan karena model ini sudah mengatasi dua masalah tersebuit. Asumsi pertama yang harus dipenuhi adalah asumsi normalitas. Berdasarkan hasil uji Jarque Bera dapat disimpulkan bahwa residual berdistribusi normal sehingga asumsi normalitas terpenuhi. Asumsi kedua yang harus dipenuhi adalah asumsi nonmultikolinearitas. Uji yang digunakan adalah menggunakan nilai VIF dimana nilai VIF tiap variabel independen harus kurang dari 10 agar asumsi nonmultikolinearitas terpenuhi. Berdasarkan tabel dibawah dapat dilihat nilai VIF tiap variabel independen bernilai kurang dari 10 sehingga asumsi nonmultikolinearitas terpenuhi.

Tabel 2. Hasil uji nonmultikolinearitas

\begin{tabular}{cc}
\hline Variabel & VIF \\
\hline LN_KREDIT & 1,0311 \\
LN_JP & 1,0325 \\
IPM & 1,0037 \\
\hline
\end{tabular}

Setelah melalui beberapa pengujian, maka diperoleh model sebagai berikut :

$$
\widehat{T P T}_{i t}=\left(28,6337+\mu_{i}\right)-(0,9142) L N_{-} K R E D I T_{i t}^{*}+(2,4073) L N_{\_} J P_{i t}^{*}-(0,3974) I P M_{i t}^{*}
$$

Dari model tersebut diperoleh nilai $R$-square Adjusted sebesar 0,7873 mengindikasikan bahwa variasi variabel dependen dapat dijelaskan oleh variabel dalam model dan sisanya dijelaskan oleh variabel diluar model. Sebesar 78,73 persen variasi yang terjadi pada TPT di Provinsi Jawa Barat dapat dijelaskan oleh variabel kredit UMKM, jumlah penduduk, IPM, sedangkan sebesar 21,27 persen sisanya dijelaskan oleh variabel lain. Untuk melihat apakah variabel-variabel tersebut berpengaruh secara bersama-sama dalam model adalah dengan melakukan overall test dengan F-statistic. Berdasarkan nilai prob(F-statistic) yang bernilai lebih kecil dari tingkat signifikansi sepuluh persen. Sehingga dapat disimpulkan bahwa minimal terdapat satu variabel independen yang berpengaruh signifikan terhadap variabel dependen.

Berdasarkan hasil estimasi, dapat dilihat bahwa kredit UMKM berpengaruh negatif dan signifikan terhadap TPT. Hal tersebut dapat dilihat dari nilai $t$-statistic $(-1,7175)$ yang berada diluar wilayah kritis $-t_{(0,05 ; 101)}=-1,6601$ dan juga dapat dilihat dari nilai $p$-value $(0,0890)$ yang lebih kecil dari tingkat signifikansi 10 persen. Sehingga setiap kenaikan 1 persentase dari kredit UMKM akan menurunkan TPT sebesar 0,9142 persen dengan asumsi variabel-variabel bebas lainnya konstan. Sejalan dengan penelitian yang dilakukan Manihuruk dan Meirinaldi (2018) bahwa pemberian kredit UMKM oleh bank BUMN dapat mengurangi tingkat pengangguran di Indonesia. Hal ini menunjukkan bahwa pemberian kredit UMKM dapat berdampak positif bagi ketenagakerjaan. Dengan pemberian kredit maka UMKM dapat mempertahankan bahkan mengembangkan usahanya, sehingga semakin besar UMKM yang ada maka semakin besar terbuka lapangan pekerjaan. Dengan meluasnya lapangan pekerjaan maka kesempatan kerja akan meningkat dan angka pengangguran dapat berkurang. Sebagaimana yang dinyatakan oleh Ncanywa dan Getye (2016) dalam penelitiannya bahwa pembiayaan kredit kecil terkadang direkomendasikan sebagai alat untuk mengurangi pengangguran dan dapat berdampak positif pada penciptaan lapangan kerja di Afrika Selatan. Sipahutar, 
Oktaviani, Siregar, dan Juanda (2016) juga menyatakan dengan pemberian kredit UMKM maka akan memperluas ketersediaan modal dan likuiditas sehingga meningkatkan bisnis di sektor riil yang berimbas pada meningkatnya permintaan tenaga kerja dan menurunkan tingkat pengangguran.

Selanjutnya, variabel jumlah penduduk berpengaruh signifikan positif terhadap TPT. Hal tersebut dapat dilihat dari nilai $t$-statistic $(30,2219)$ yang berada didalam wilayah kritis $t_{(0,05 ; 101)}=1,6601$ dan juga dapat dilihat dari nilai $p$-value $(0,0000)$ yang lebih kecil dari tingkat signifikansi 10 persen. Sehingga setiap kenaikan 1 persentase dari jumlah penduduk akan meningkatkan TPT sebesar 2,4073 persen dengan asumsi variabel-variabel bebas lainnya konstan. Hasil ini sejalan dengan penelitian yang dilakukan Sidania, Wibisono, dan Purtomo (2017). Peningkatan jumlah penduduk sejalan dengan peningkatan jumlah tenaga kerja. Peningkatan jumlah tenaga kerja yang tidak sesuai dengan penyerapan tenaga kerja akan menyebabkan peningkatan jumlah pengangguran. Oleh karena itu, dapat disimpulkan bahwa peningkatan jumlah penduduk akan menyebabkan peningkatan TPT.

Terakhir, variabel IPM berpengaruh negatif dan signifikan terhadap TPT. Hal tersebut dapat dilihat dari nilai $t$-statistic $(-5,4813)$ yang berada didalam wilayah kritis $-t_{(0,05 ; 101)}=-1,6601$ dan juga dapat dilihat dari nilai $p$-value $(0,0000)$ yang lebih kecil dari tingkat signifikansi 10 persen. Sehingga setiap kenaikan 1 satuan dari IPM akan menurunkan TPT sebesar 0,3974 persen dengan asumsi variabel-variabel bebas lainnya konstan. Hal ini sejalan dengan penelitian Mahroji dan Nurkhasanah (2019). Apabila IPM meningkat maka tingkat pengangguran menurun. Kenaikan IPM menyebabkan meningkatnya kualitas angkatan kerja di suatu wilayah baik dari segi pendidikan maupun skill. Dengan meningkatnya kualitas angkatan kerja maka mereka mampu memenuhi standar yang dibutuhkan lapangan kerja sehingga semakin banyak angkatan kerja yang terserap dan menurunkan tingkat pengangguran.

Terdapat efek dari setiap individu karena model yang digunakan adalah FEM. Berdasarkan hasil estimasi dapat diketahui bahwa Kota Sukabumi memiliki efek individu tertinggi dengan nilai 4,5933 dan Kabupaten Majalengka memiliki efek individu terendah dengan nilai -5,2086. Artinya, saat semua variabel bebas dalam model memiliki nilai yang sama maka Kabupaten Bekasi memiliki TPT tertinggi dan sebaliknya Kabupaten Majalengka memiliki TPT terendah jika dibandingkan dengan seluruh kabupaten/kota di Provinsi Jawa Barat.

\section{KESIMPULAN}

Berdasarkan penelitian yang telah dilakukan dapat disimpulkan bahwa kredit kepada UMKM berpengaruh negatif signifikan terhadap tingkat pengangguran. Dengan cara ini, ketika jumlah pinjaman kepada UMKM meningkat, tingkat pengangguran akan berkurang. Hal ini terjadi karena dengan meningkatkan jumlah pinjaman kepada UMKM maka modal UMKM untuk pengembangan usaha dapat ditingkatkan. Dengan cara ini, dengan berkembangnya usaha kecil, menengah dan mikro, kesempatan kerja dapat diperluas, mempengaruhi penyerapan angkatan kerja yang ada, dan tingkat pengangguran akan berkurang.

Selain itu, hasil penelitian ini juga menemukan variabel lain yang juga mempengaruhi tingkat pengangguran, salah satunya adalah jumlah penduduk. Jumlah penduduk berpengaruh signifikan positif terhadap tingkat pengangguran, sehingga ketika jumlah penduduk bertambah maka tingkat pengangguran akan meningkat. Peningkatan jumlah penduduk yang disebabkan oleh kelahiran atau migrasi akan menyebabkan peningkatan jumlah tenaga kerja. Peningkatan jumlah tenaga kerja akan menyebabkan persaingan lapangan kerja yang semakin ketat, yang akan menyebabkan tenaga kerja nonkompetitif tidak dapat memperoleh pekerjaan dan menjadi pengangguran. Oleh karena itu, semakin bertambahnya jumlah penduduk provinsi Jawa Barat maka tingkat pengangguran akan semakin meningkat. Variabel lain yang mempengaruhi tingkat pengangguran adalah Indeks Pembangunan Manusia (IPM). IPM memiliki dampak negatif yang signifikan terhadap tingkat pengangguran, sehingga ketika IPM meningkat maka tingkat pengangguran akan menurun. IPM merupakan indikator kualitas sumber daya manusia di suatu daerah. Tingginya indeks pembangunan manusia menunjukkan bahwa kualitas manusia di wilayah tersebut tinggi, sehingga kualitas manusia di bidang pendidikan dan kesehatan sangat tinggi dan angkatan kerja dapat terserap dengan baik oleh lapangan kerja. Oleh karena itu, tingkat pengangguran dapat dikurangi dengan meningkatkan IPM. 


\section{DAFTAR PUSTAKA}

Badan Perencanaan dan Pembangunan Nasional. (2017). Visi dan Arah Pembangunan Jangka Panjang Tahun 2005-2025. Jakarta: Bappenas.

Badan Pusat Statistik. (n.d.). Retrieved November 20, 2020, from bps.go.id: https://www.bps.go.id/dynamictable/2020/02/19/1774/tingkat-pengangguran-terbuka-tpt-menurutprovinsi-1986---2019.html

Badan Pusat Statistik Jawa Barat. (2016). Provinsi Jawa Barat Dalam Angka 2016. Bandung: BPS.

Badan Pusat Statistik Jawa Barat. (2017). Provinsi Jawa Barat Dalam Angka 2017. Bandung: BPS.

Badan Pusat Statistik Jawa Barat. (2018). Provinsi Jawa Barat Dalam Angka 2018. Bandung: BPS.

Badan Pusat Statistik Jawa Barat. (2019). Provinsi Jawa Barat Dalam Angka 2019. Bandung: BPS.

Badan Pusat Statistik Jawa Barat. (2020). Provinsi Jawa Barat Dalam Angka 2020. Bandung: BPS.

Fadli, M. (2018). Estimasi Tingkat Pengangguran Terbuka Kabupaten/Kota Menggunakan Model FayHerriot With Measurement Error di Provinsi Banten dan Jawa Barat Tahun 2016. Jakarta: Politeknik Statistika STIS.

Gujarati, D. N. (2004). Basic Econometrics (4th ed.). New York: The Mac Graw Hill Companies.

Kementrian Koperasi dan Usaha Kecil dan Menengah. (2019). Perkembangan Data Usaha Mikro, Kecil, Menengah (UMKM) dan Usaha Besar (UB) Tahun 2015-2019. Jakarta: Kementrian Koperasi dan UMKM.

Lindiarta, A. (2014). Analisis Pengaruh Tingkat Upah Minimum, Inflasi, dan Jumlah Penduduk Terhadap Pengangguran di Kota Malang 1996-2013. Jurnal Ekonomi Pembangunan.

Mahroji, D., \& Nurkhasanah, I. (2019). Pengaruh Indeks Pembangunan Manusia Terhadap Tingkat Pengangguran di Provinsi Banten. Jurnal Ekonomi-Qu, 9(1).

Manihuruk, C., \& Meirinaldi. (2018). Pengaruh Modal Bank, Alokasi Kredit Dana Pihak Ketiga, dan Jumlah Kantor Cabang Bank BUMN Persero terhadap Jumlah Kredit Usaha Kecil dan Implikasinya pada Tingkat Pengangguran. Jurnal Ekonomi, 20(3).

Mankiw, N. G. (2007). Macroeconomics (6th ed.). New York: Worth Publisher.

Michael P Todaro, S. C. (2011). Pembangunan Ekonomi (9th ed.). Jakarta: Erlangga.

Ncanywa, T., \& Getye, S. (2016). Micro-credit Finance and Unemployement in South Africa. International Journal of Economics and Finance Studies, 8(2).

Othman, A., \& Gloaguen, R. (2013). River Courses Affected by Landslides and Implications for Hazard Assessment: A High Resolution Remote Sensing Case Study in NE Iraq-W Iran. Remote Sensing, 5(3), 1024-1044.

Priastiwi, D., \& Handayani, H. (2019). Analisis Pengaruh Jumlah Penduduk, Pendidikan, Upah Minimum, dan PDRB Terhadap Tingkat Pengangguran Terbuka di Provinsi Jawa Tengah. Diponegoro Journal of Economics, 1(1), 159.

Sidania, J., Wibisono, S., \& Purtomo, R. (2017). Determinan Tingkat Pengangguran Terbuka di Provinsi Banten Tahun 2008-2013. E-Journal Ekonomi Bisnis dan Akuntansi, 4(2), 169-172.

Sipahutar, M. A., Oktaviani, R., Siregar, H., \& Juanda, B. (2016). Effects Of Credit On Economic Growth, Unemployement and Poverty. Jurnal Ekonomi Pembangunan, 17(1), 37-49.

Sukirno, S. (2004). Makroekonomi : Teori Pengantar. Jakarta: PT. Raja Grafindo Persada. 